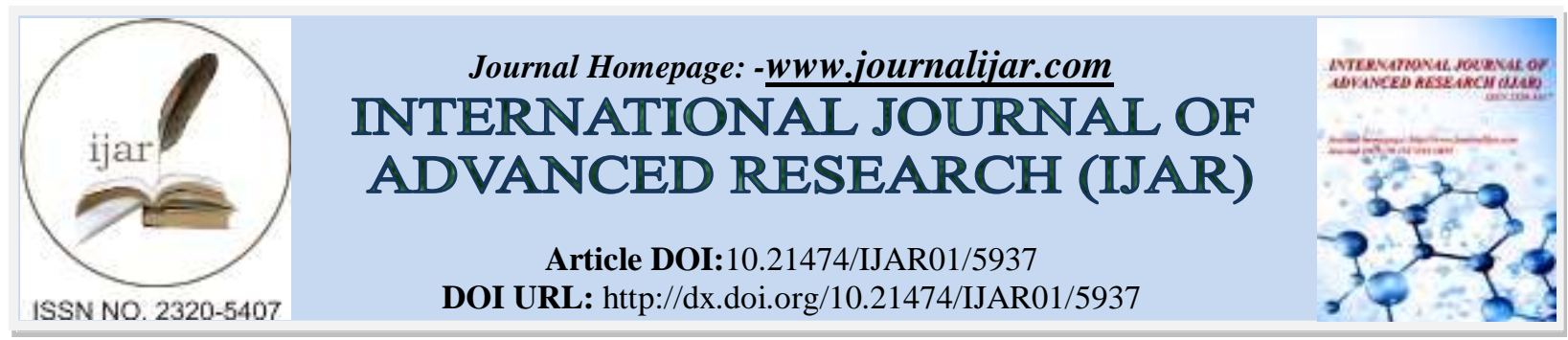

RESEARCH ARTICLE

\title{
STUDENTS' PERSPECTIVES OF NON-ENGLISH PROGRAM IN LEARNING ENGLISH THROUGH WEBSITE.
}

RisaMufliharsi and Eva NurulCandra.

Department of English Education and Arts, University of Indraprasta PGRI.

\section{Manuscript Info}

Manuscript History

Received: 01 October 2017

Final Accepted: 03 November 2017

Published: December 2017

Key words:-

Students' Perspective, ESP, Website.

\begin{abstract}
The research purposes 1) to improve students' of non English department perspective in learning English using new model through ESP course which implemented in website that deals with students' needs in non-English program first grade. 2) to develop course which is implemented in a model. 3) To find out the effectiveness of the course design. The research uses qualitative and quantitative data (research and development) to find out credible data which have been confirmed by the writers. Then, the writers analyze the data which have been taken .The procedure of collecting the data:1) Writers found out the need analysis of using ESP materials by using questionare, 2) The writers design the course 3 ) The design is analyzed by expert judgement 4) the design is tested in small group, 5) validation, evaluatiooon, and revised model in part 16 ) the design is implemented in effectively tested. The result of this research is website "inggris123" which consisted of English vocabulary, reading texts, and exercises which are related to students' needs in first grade in non English program. 51,6\% of students answer that the website covered their needs. Then $57,3 \%$ answer that the website facilitate them in learning English.
\end{abstract}

Copy Right, IJAR, 2017,. All rights reserved.

\section{Introduction:-}

As a tool in communication nowadays, English is not only used by natives, but also many communities. The differences of using English are in their purposes. So that, there are many parts of English which are related to the purposes, such as ESP (English for Specific Purpose), ESL (English For Second Language), EFL (English For Foreign Language), etc.

In this study, writers concern with the instruction of English in Non-English Department. The instruction of English in Non-English Department in Indraprasta PGRI University is still using General English for their syllabus. Whereas, General English fundamentaly is not related to students' needs in non-English program because they do not need to learn four basic skills in English only in one term. If this condition still running, they still think of English is difficult because the output of the study is listening, speaking, reading, and writing. Moreover, the most of them have less vocabulary and grammar which are basic in English. Related to this condition, the writers took students' perspectives from 5 universities as samples to find out the need analysis of non Englishdepartement. They are Syarif Hidayatullah Ciputat Banten Islamic (chemistry major) ,Mercubuana university (informatics techniques), State University of Jakarta (chemistry education major), College of Marine (nautica major), and Indraprasta PGRI 
university (Science Education). Based on the questionares, the writers infer: 1) The content of English subject doesn't cover the needs of non-English program, 2)The course and materials are too difficut, 3) In general, the students should find out various website as reference to fill their English task.

In real condition, the writers observe that the students sometimes do not get correct information which are related to their need in doing English task. Moreover, the sources are not relevant to the materials.

In fact, students realize that English is important for their future. Therefore, they have to change their attitude, motivation, and behavior in learning English. Many factors can convert their behavior. One of them is English material in their classroom. The lecturer should realize that the students need English for achieving their goals. So that, they need English to spesific purpose, because mastery in English is not their goals. That is why English lecturer in non-English program should know which materials that should students must have relation to major that they have chosen. Actually, they need one webstite which covers their needs in doing their tasks

Related to the situations given, the writers assume that it is needed to change the course and changing the objectives. Next, the lectures classify the materials and choose the spesific materials that ussually related to work area. If the lecturer focuses in the objective which is needed by the students, the students will encourage themself to learn English actively because they must enrich themself for the future. After that, the lecturer can use media which is close to students. In this study, the writers uses ESP materials and implement the materials by using website. Website is chosen because it can be accessed by everyone in everywhere. Hopefully, by using website, students can increase their ability in English.

\section{Research Questions:-}

1. Does Website Improve Students' Perspective in Learning English in Non-English Department?

2. How The Influence of Website in Students' Perspective of Learning English in Non-English Department?

\section{Literature Review:-}

\section{Developing Material:-}

Commonly, the goals of language teaching program usually derive from the reason why people should learn English. Related to this situation, there are many regulations, patterns to confine the function of the language used. Mcdonough and Shaw (2005:5) define about framework. The frame work related to context and syllabus, "The meant by framework is started from the view that materials and methods cannot been in isolation, but are embedded within a boarder marker professional context." It can be stated there are relationship among materials, method and context.

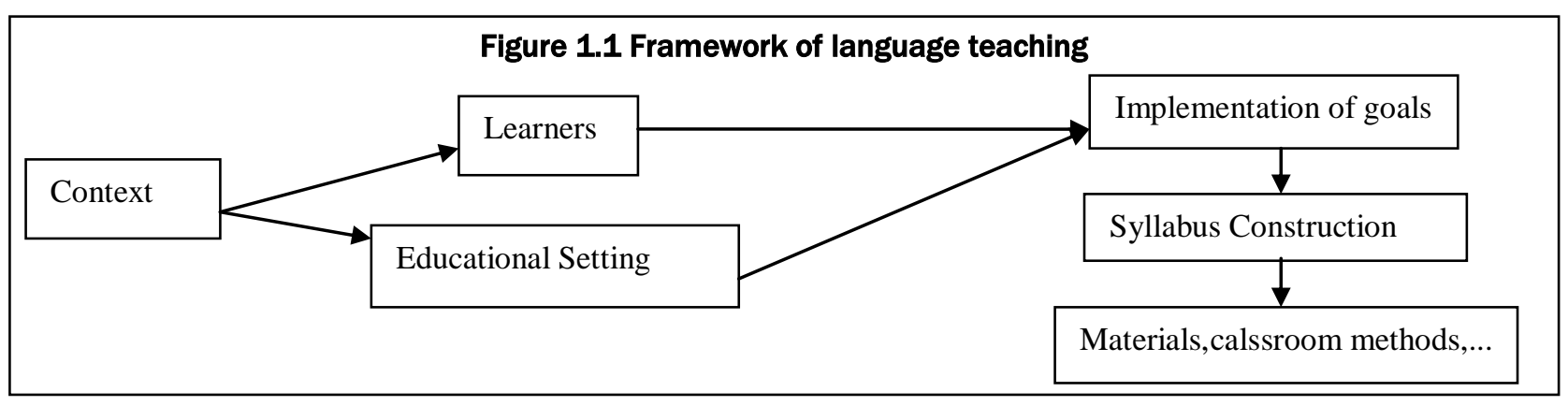

type of syllabus content and specification. The broad syllabus has direct implications for more detailed design and selection of materials and tests, the planning of individual course and the management of the classroom itself.

As seen in the figure, learner is one of variable which influences the implementation of goals, the lecturer should concern the students' interest in learning to achieve the goals. It means if lecturer wants her or his students success in learning English, the lecturer should plan what students need. Specially for non English program which needs not for being mastery in language, he only uses English as a tool to get needed job. To solve this problem, the writer uses ESP course design which is designed from students' needs in learning English related to their goals.

\section{English Spesific Purpose:-}

ESP (English for Spesific Purpose) is based on designing courses to meet learners' needs. ESP is is only a branch of EFL/ESL and is one variety of many kinds of language teaching. Chen (2006) stated "ESP course designers should 
explore and identify the learners' potential needs in the first place." Based on it, lecturer should develop and find the main elements of English related to the learners. To carry out the students' need, the writer did need analysis from students' perspective in learning English. Need analysis is a key of answering what students' need.

Barnard and Zemacheditted by Tomlinson(2007) added, "ESP is an umbrella term that refers to the teaching of English to students who are learning the language for a particular work or study-related person. They are: EOP and EAP. " It means ESP covers an enormous range of content area.

Dudley Evans and St John (1998) in Jiajian (2007) includes consideration of the following aspects: 1)Professional information about the learners: the tasks and activities learners are/will be using English for- target situation analysis and objective needs. 2) Personal information about the learners: factors which may affect the way they learn such as previous learning experiences, cultural information, reasons for attending the course and expectations of it, attitude to Englishwants, means, subjective needs. 3) English language information about the learners: what their current skills and language use are- present situation analysis- which allows us to assess (D). 4) The learners' lacks: the gap between (C) and (A)- lacks. 5). Language learning information: effective ways of learning the skills and language in (D)- learning needs. 6). Professional communication information about (A): knowledge of how language and skills are used in the target situation- linguistic analysis, discourse analysis, genre analysis. 7) What is wanted from the course. H. Information about the environment in which the course will be run - means analysis.

Related to the discussions above, the writers design courses which reflect the materials which needed by students in visual design communication program in four steps, they are:1) need analysis, 2)course , 3)material selection, 4) teaching and learning evaluation.

\section{Definition of Website:-}

Website, web, or site is a central location of various web pages that are all related and can be accessed by visiting the home page using a browser (https://www.computerhope.com). The web address can be reached through internet connection. The elements of websites are web address or web pages, homepage, web server. Each elements is related to each other. To view a website requires a browser. Then, one can open the website by entering the URL in the address bar.

By using website, everyone will read the information contained on each web page, and if there are any interesting hyperlinks, he will follow those links by clicking on them to find out more information or to perform a task. Besides, one can also listen to music, watch videos, shop, communicate, and much more on many websites.

Because of many advantages in use, website has different purposes depending on who the intended audience is. Some websites are geared towards selling products and other websites are geared towards providing practical information, while others are merely for entertainment. They are:

a. Informative / Practical Information Websites

The purpose of an information centric website is to convey specific, helpful information to a specific user/audience so that the reader learns something new or understands a topic better. These websites are geared around more actionable information and may contain tips and tricks, fix and repair, guidance, support information, directions, instructions, etc.

b. Entertainment Websites

These websites showcase entertaining information for visitors. They are: Online magazines, gossip oriented websites, celebrity news, sports coverage, movies, the arts, humorous websites, etc. These websites are designed to be easy to navigate and frequently updated in order to keep users coming back for more information. They can be made more engaging by using dynamic content, such as videos, podcasts, slideshows, etc.

c. E-Commerce Websites

The purpose of e-commerce websites are to sell products to users. The most successful websites are carefully optimized to achieve a high percentage of purchases. To achieve success e-commerce websites need to integrate all of the latest online closing \& upsell techniques available which have been proven to increase the chances that a visitor will purchase.

d. Service-Based Business Websites

The purpose of a service-based business website is to convince website visitors that they should become customers of the service company. This is done by positioning the company as a dependable, trust worthy and experienced service provider in the target market.

e. Blog 
The purpose of a blog is to provide a regularly updated website or web page, typically one run by an individual or small group, that is written in an informal or conversational style.

\section{f. Social Media Websites}

The purpose of social media websites are to make it very easy to share and connect with friends, family, co-workers, acquaintances and even strangers. (https:/www.cleart.com/what-is-the-purpose-of-a-website.html)

Based on the definitions above, it can be concluded that website is a central location of various web pages that are all related and can be accessed by visiting the home page using a browser. It has many purposes which depended by who the intended audience is. Some websites are geared towards selling products and other websites are geared towards providing practical information, while others are merely for entertainment.

Related to the purpose, the writers design a model of course using website. In website, the students would learn English in less pressure because the most of them tend to use media in learning. Besides, they could repeat the material by doing the exercise everytime they need.

\section{Methodology:-}

The research uses quantitative and qualitative data in research and development $(\mathrm{R}$ and $\mathrm{D})$ research. The research is conducted in visual design communication program in first grade students that consisted of 45 students. The procedure of collecting the data:

1. Writers found out the need analysis of using ESP materials by using questionare

2. Writers analyzed the data

3. Writers asked expert judgement related to the instrument (collaboration with statistics lecturer)

4. Writers grouped the data in validity and reliability

5. Writers designed syllabus and the course in website

6. Writers tested the course to a group of students in visual design communication program

7. Writers evaluated the result which are collected by using questionares

\section{Findings and Discussion:-}

\section{Need Analysis}

The writer usesquestionare to find out the students' needs. The indicators related to Ahmad H.P are:1) Benar dan aktual, 2) Penting untuk dipelajari, 3) Bermanfaat dalam kecakapan hidup, 4) Layak dipelajari, 5) Menarik minat.

Related to data which confirmed by the writers:

1. Based on the validity and and reliability of designing test, one item is not valid. So, it can be summarized that all the items covered the needs of the students.

2. The reliability of the instrument is 0,894 . It means coefficient of reliability is high

3. $70 \%$ students thought the materials are not related to the major.

\section{Course Design:-}

The writers choose the themes and find out the objective of the study which is encourage students' perspectives in English. The course is conducted in three times in classroom and using media in practice. The writers can find out students' skill in reading comprehension, vocabulary, and writing.

Table 1:- Course Design in Visual Design Communication

\begin{tabular}{|l|l|l|}
\hline Topics & $\begin{array}{l}\text { Language Related Genre and } \\
\text { Function }\end{array}$ & Language Skills and Task \\
\hline Technology & $\begin{array}{l}\text { - Definition } \\
\text { - General to spesific description } \\
- \text { Describe the text and selected the } \\
\text { grammar (Past Tense) } \\
\text { - Find the appropriate words (regular } \\
\text { and irregular words) }\end{array}$ & $\begin{array}{l}\text { - Reading Android, PC, Tablet } \\
\text { - Fill the blank related to the text } \\
\text { given } \\
\text { - Decide appropriate words related } \\
\text { to regular and irregular form }\end{array}$ \\
\hline
\end{tabular}




\section{Material Selection:-}

The writers have set the materials in website including the objective, text, and exercises related to the material that chosen in website, named "inggris123". The function of this website is accomodating and facilitating the students in improving their English.
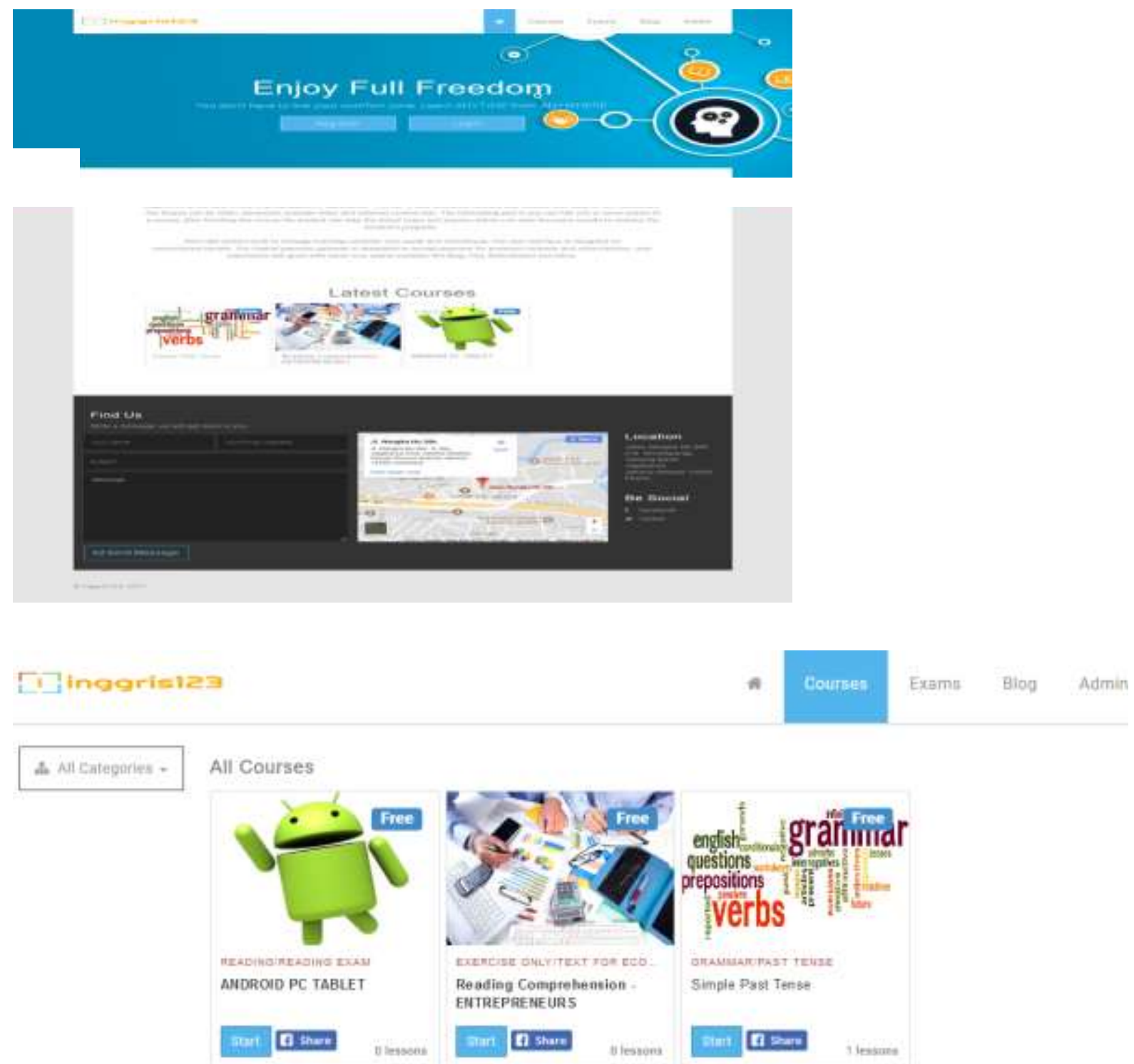

Teaching and Learning Evaluation:-

After instruction, writers got evaluation from the students for knowing their concerning in learning English through website by doing questioners. The items refers to their satisfaction, their interest, their need, their achievement, and their suggestions.

Related to the students' answers, 51,6 \% of students answer that the website covered their needs. Then 57,3\% answer that the website facilitate them in learning English. In othe words, the websites can increase their English naturally because they do not get high pressure in doing exercise. 


\section{Conclusion:-}

Based on the procedures that has been through, the writers can conclude:

1. By changing the syllabus to be ESP syllabus will improve students' perspective in learning English at non English program. In ESP, lecturer has selected the materials which are related to their major or job in the future. So that, the students will be familiar in it and can explore their skill in English related to their job. They need English to support their carrier and ability to find out their needed job. After changing the syllabus, lecturer should change the material and using related media to improve students' ability. Website can be one of media which is close to the students who visual design communication program. They tent to love something related to technology or update information. It is caused by they are required to be multimedia designer who is always in up to date condition.

2. The implementation materials in website in Non-English Department influences students' perspective in learning English vocabulary. In fact, Based on the students' answers, 51,6 \% of students answer that the website covered their needs. Then 57,3\% answer that the website facilitate them in learning English. In othe words, the website influence students' perspectives in learning English because they can learn English naturally without getting high pressure in doing exercise.

\section{References:-}

1. Jiajing, Gao. (2007)Designing an ESP course for Chinese University Students of Business. Asian ESP Journal Online, 3 (1), 98-107. Retrieved April 2007 from http://asian-esp-journal.com/wpcontent/uploads/2016/01/AESp-Volume-3-Issue-1-Apri-2007.pdf

2. McDonough, Jo and Christoper Shaw (2005). Materials and Methods in ELT. United Kingdom: Blackwell Publishing

3. P ,Achmad H., (2007) PendekatanWacanaDalamPembelajaranMenulis. Jakarta: JurnalBahtera No.11 PPs UNJ, 2007

4. Tomlinson, Brian. (2007). Developing Materials For Language Teaching. London: Continuum.

5. Yong, C. (2006). From common core to specific. Asian ESP Journal Online, 1(3), 24-47. Retrieved November 28th, 2006 from http://www. asian-esp-journal.com/June_2006_vc.php

6. https://www.computerhope.com accessed in 14/11/2017 at 12.30 p.m

7. https://www.cleart.com/what-is-the-purpose-of-a-website.html accessed in 15/11/2017 at 15.00 